\title{
Left ventricular torsional hysteresis in patients with hypertension: a global parameter for diastolic function
}

Chun Schiros ${ }^{1}$, Ravi V Desai', Bharath Ambale Venkatesh'1, Mustafa Ahmed', Shilpi Agarwal', Steven Lloyd ${ }^{1}$, David Calhoun', David McGiffin', Thomas S Denney², Louis J Dell'Italia', Himanshu Gupta ${ }^{1 *}$

From 16th Annual SCMR Scientific Sessions

San Francisco, CA, USA. 31 January - 3 February 2013

\section{Background}

Torsion is an important determinant of left ventricular (LV) systolic and diastolic function. We hypothesized that the area within the torsion volume loop, called the torsional hysteresis $(\mathrm{TH})$, may be an important parameter of diastolic function (DD).

\section{Methods}

60 resistant hypertension (HTN) patients, 40 healthy controls were studied using cardiac MRI with tissue tagging. Volumetric and torsional parameters were evaluated.

\section{Results}

HTN patients demonstrated concentric remodeling. All HTN patients had preserved ejection fraction $(>55 \%)$ and normalized peak ejection rate was significantly greater in HTN vs. controls. HTN patients had significantly decreased MRI-measured early filling rate, E/A ratio $(1.33 \pm 1.13$ vs. $2.19 \pm 1.07, \mathrm{P}<0.0001)$ and early diastolic

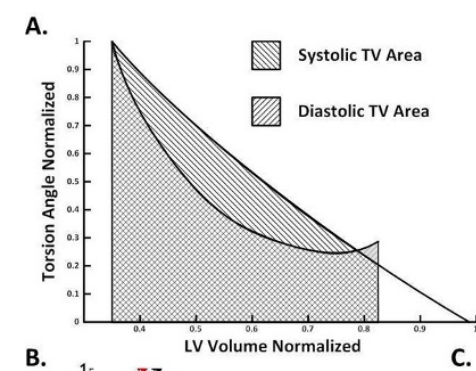

B.

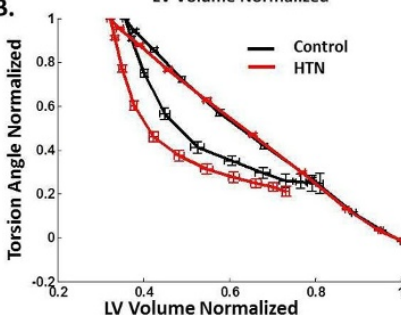

c.

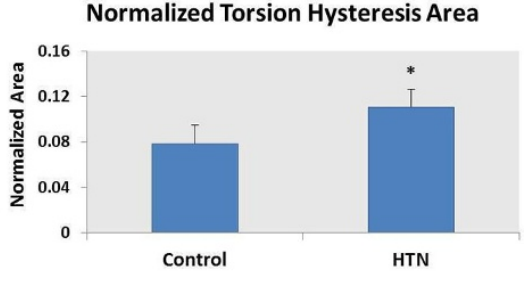

Figure 1 Schematic diagram for calculating torsional hysteresis-the area within the systolic and diastolic arm of the normalized torsion volume (TV) curves (A), normalized TV curves for the two groups (B) and calculated torsional hysteresis (C). Torsion hysteresis is greater in the HTN vs. Control. *, P<0.001 vs. Control; Data points are expressed as mean \pm standard error.

${ }^{1}$ Medicine, University of Alabama at Birmingham, Birmingham, AL, USA

Full list of author information is available at the end of the article

C 2013 Schiros et al; licensee BioMed Central Ltd. This is an Open Access article distributed under the terms of the Creative Commons 


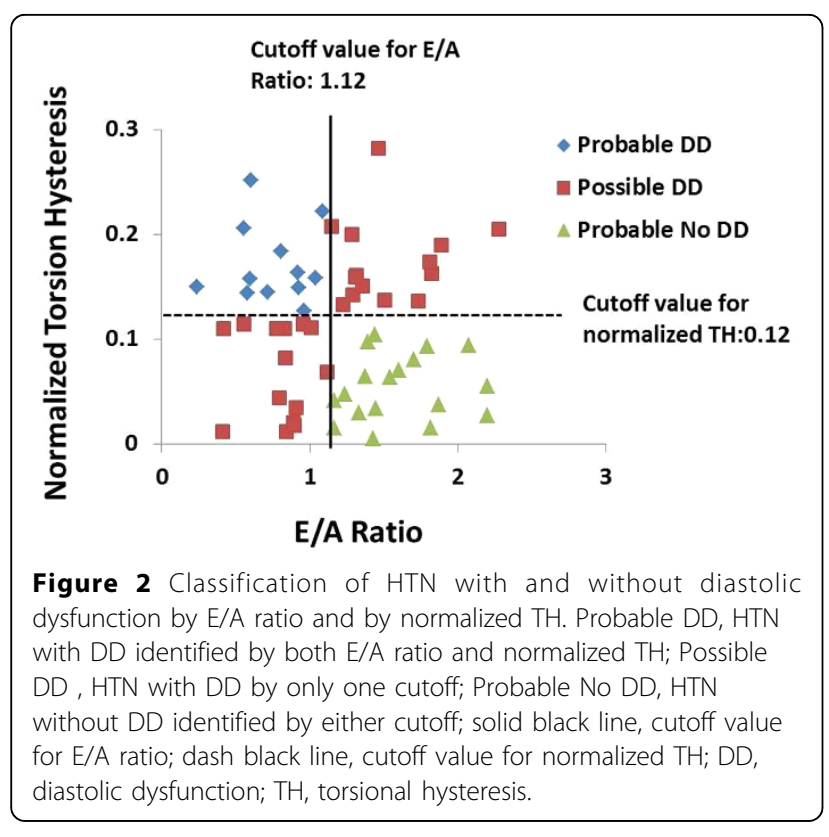

mitral annulus velocity normalized to LV length (66.23 \pm 20.65 vs. $85.67 \pm 29.96 \%, \mathrm{P}<0.001)$ vs. controls. Furthermore, the normalized $\mathrm{TH}$ was significantly greater in HTN compared controls $(0.11 \pm 0.07$ vs. $0.079 \pm 0.045$, $\mathrm{P}<0.001$ ) (Figure 1). LV normalized TH best correlated with E/A ratio $(\mathrm{r}=-0.23, \mathrm{P}=0.025)$ but not with $\mathrm{LVmass} /$ volume. Mean normalized TH plus 1 standard deviation and mean E/A ratio minus 1 standard deviation of controls were used as cutoffs to identify DD in HTN respectively. Both cutoffs identified $\sim 50 \%$ HTN patients with DD ( 27 by normalized TH, 28 by E/A ratio), among which 13 patients were identified with DD by both cutoffs, as shown in Figure 2.

\section{Conclusions}

$\mathrm{TH}$ as measured by area within torsion volume loops was significantly increased in hypertensive concentric remodeling with associated DD. TH took into account not only active and passive recoil processes of the LV diastolic phase but also the systolic phase and represents a heretofore new assessment of diastolic function.

\section{Funding}

NIH-NHLBI P50-HL077100.

\section{Author details}

${ }^{1}$ Medicine, University of Alabama at Birmingham, Birmingham, AL, USA.

EElectrical and Computer Engineering, Auburn University, Auburn, AL, USA.

Published: 30 January 2013
doi:10.1186/1532-429X-15-S1-028

Cite this article as: Schiros et al:: Left ventricular torsional hysteresis in patients with hypertension: a global parameter for diastolic function.

Journal of Cardiovascular Magnetic Resonance 2013 15(Suppl 1):O28.
Submit your next manuscript to BioMed Central and take full advantage of:

- Convenient online submission

- Thorough peer review

- No space constraints or color figure charges

- Immediate publication on acceptance

- Inclusion in PubMed, CAS, Scopus and Google Scholar

- Research which is freely available for redistribution

Submit your manuscript at www.biomedcentral.com/submit
C Biomed Central 